\title{
Article
}

http://dx.doi.org/10.11646/phytotaxa.234.2.4

\section{New species of Preussia with 8-celled ascospores (Sporormiaceae, Pleosporales, Ascomycota)}

\author{
ÅSA KRUYS \\ Systematic Biology, Department of Organismal Biology, Evolutionary Biology Centre, Uppsala University, Norbyvägen 18D, SE-752 36 \\ Uppsala, Sweden.Email: asakruys@gmail.com
}

\begin{abstract}
The focus of this study is on Preussia sensu lato species with 8-celled ascospores. Two new species, P. alpina and P. octocylindrospora are introduced based on morphological characters and discussed in relation to similar species in the genus. New records are provided from Sporormiella corynespora, S. octomegaspora, P. octomera and P. octonalis. This greatly expands or reduces their geographical distribution ranges, as well as substrate preferences. In addition, a key to the coprophilous species with 8-celled ascospores is provided.
\end{abstract}

Key words: Dothideomycetes, Fungi, systematics, taxonomy

\section{Introduction}

Preussia sensu lato (incl. Sporormiella) belongs in the family Sporormiaceae (Dothideomycetes, sensu Hyde et al. 2013, Wijayawardene et al. 2014) and is one of the most abundant and species-rich groups of fungi living on animal dung. They are cosmopolitan and grow on a large variety of dung types, from the smallest vole dropping to large elephant dung (Ahmed \& Cain 1972, Khan \& Cain 1979, Doveri 2004, Bell 2005, Barr 2009, Mungai et al. 2012). Although the majority of the species in the genus are coprophilous, they also occur on other substrates like plant debris, soil and wood (Cain 1961, Dugan et al. 1995, Guarro et al. 1997), or as endophytes in plants (e.g. Porras-Alfaro et al. 2008, 2011, Herrera et al. 2010, 2011, Danielsen et al. 2012). Preussia and Sporormiella have for long been considered closely related (von Arx \& Storm 1967, von Arx \& Müller 1975, Eriksson 1981), and I treat them as synonyms since molecular phylogenetic studies do not support a differentiation of Preussia from Sporormiella (Kruys \& Wedin 2009, Mapperson et al. 2014). The taxon currently includes more than 100 species (Index Fungorum 2015). The species are morphologically characterized by brown to black pseudothecia, fissitunicate asci, and dark brown, septate ascospores. A gelatinous sheath covers each ascospore and in general each cell has a germ slit.

The majority of the species have 4-celled ascospores, but there are various multi-celled taxa (Ahmed \& Cain 1972). The focus of this study is on the 8-celled Preussia species, and the purpose is to describe new species and records. The ascospores of this group vary in shape and size and they do not form one monophyletic clade (Kruys \& Wedin 2009).

\section{Material and Methods}

This study is to large extent based on Prof. em. Nils Lundqvist's specimens, deposited in the Museum of Evolution herbarium at Uppsala University, Sweden (UPS). Observations and measurements were made with a Leica M125 dissecting microscope, and an Olympus BX50 light microscope. Measurements of ascospores and pseudoparaphyses were made in water at $100 \times$ magnification with oil immersion and $0.5 \mu \mathrm{m}$ precision, or at $40 \times$ magnification for the very long measurements. Other characters were measured at $40 \times$ magnifications. Measurements are presented as the range of values observed, with outlying extremes within parentheses. The size ranges are based on 20 measurements or less, depending on the amount of material available. Photographs were taken with a Nikon DS-Vil camera and have been edited in Adobe Photoshop CS6. 


\section{Results}

\section{New species}

Preussia alpina N. Lundq. \& Kruys, sp. nov. (Fig. 1)

MycoBank no.: MB811845

Type:-SWEDEN. Härjedalen: Storsjö par., Mt. Torkilstöten, above the tree-line, on grouse dung (Lagopus) in moist chamber, Uppsala, 18 July 1975, Nils Lundqvist $9961-c$, F-529759 (holotype UPS!).
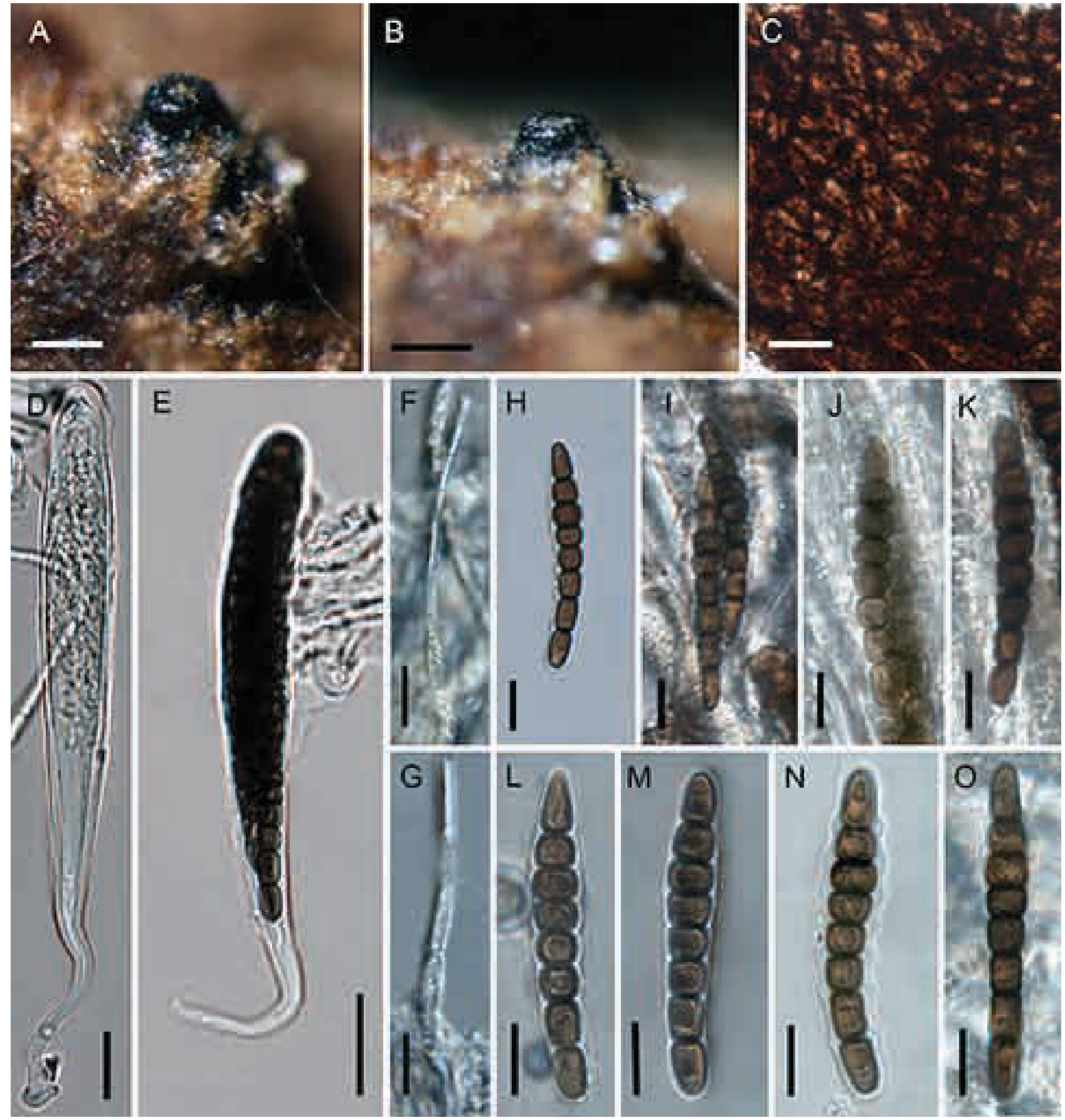

FIGURE 1. Preussia alpina A-B. ascomata, C. detail of exoperidium, D. immature ascus, E. ascus, F-G. pseudoparaphyses, H-O. ascospores. A-B, F-H, M. Coll. F-529764 (UPS), C, E, L. Coll. F-529759 (UPS), D, J. Coll. F-529761 (UPS), I. Coll. F-529762 (UPS), K. Coll. F-529758 (UPS), N-O. Coll. F-529760 (UPS). Scale bars: A-B=100 $\mu \mathrm{m}, \mathrm{C}=10 \mu \mathrm{m}, \mathrm{D}-\mathrm{E}=20 \mu \mathrm{m}, \mathrm{F}-\mathrm{O}=10 \mu \mathrm{m}$. 
Pseudothecia scattered, immersed, 320-350 diam $\times 380-390 \mu \mathrm{m}$ high, subglobose, ostiolate, dark brown to black, opaque. Neck short, papilliform, smooth, bare, black. Peridium pseudoparenchymatous. Pseudoparaphyses abundant, filiform, ca. 2-3.5 $\mu \mathrm{m}$ wide, septate, containing hyaline vacuoles, mixed with asci. Asci fissitunicate, clavate, eightspored, 145-180 × 15-23 $\mu \mathrm{m}$, with a long stalk. Ascospores eight-celled, fusiform, (40-) 45-52 $\times 6-7 \mu \mathrm{m}$, hyaline to light brown in early stages, becoming dark brown when mature, cells unequal in size, apical cell elongated, narrowing toward the apex, second cell from the upper end \pm trapezoid, third cell the broadest, third and fourth cell broader than long, fifth cell \pm square, sixth to eight cell longer than broad, basal cell rounded at apex, septa transverse, germ slits indistinct, oblique, gelatinous sheath hyaline, narrow.

Etymology:- the species epithet refers to its distribution in northern, mountain areas of Scandinavia.

Habitat and distribution:- - on dung of Lagopus in the northern, mountain areas of Scandinavia.

Specimens examined:-FINLAND. Lapponia inarensis: Utsjoki par., Utsjoki (NNE of the church), on grouse dung in moist chamber, Uppsala, 26 July 1966, Nils Lundqvist 4925-e, F-529762 (UPS!); NORWAY. Finnmark: Tana, Polmak par., Skipagurra (Skipaskaret), SW slope of Mt. Gielkaioaivve, on grouse dung in moist chamber, Uppsala, 2 August 1966, Nils Lundqvist 5159-d, F-529758 (UPS!); Finnmark: Vadsø, Varanger Peninsula, Nord-Varanger par., S of Svanevatnet (= c. $4 \mathrm{~km} \mathrm{~N}$ of Vadsø), elevation 130-160 m, on grouse dung in moist chamber, Uppsala, 27 July 1966, Nils Lundqvist 4964-c, F-529761 (UPS!); Sør-Trøndelag: 10 km SSW of Brekken, on a mountain W of Feragen, on grouse dung (Lagopus) in moist chamber, Uppsala, 16 July 1975, Nils Lundqvist 9940-c, F-529764 (UPS!); SWEDEN. Jämtland: Åre par., Snasahögarna Mts., Mt. Storsnasen, elevation 1400 m, on dung of Lagopus sp. in moist chamber, Uppsala, 27 August 1967, Kerstin Holm \& Lennart Holm, F-529760 (UPS!).

Taxonomic remarks: $-P$. alpina resembles $P$. octomera in the shape of the ascoma with a short neck, as well as the long-stalked asci. Both species have eight-celled ascospores with a largest third cell, but the ascospores of $P$. alpina are longer and narrower than those of $P$. octomera, and the shape of the ascospore cells differs. The middle ascospore cells of $P$. octomera are clearly broader than long, which is not the case in P. alpina.

Preussia octocylindrospora N. Lundq. \& Kruys, sp. nov. (Fig. 2).

MycoBank no.: MB811844

Type:-KENYA. Central: Thika Distr., c 5 km WSW of Thika, B. Harris Farm, elevation 1500 m, lat. -1.06667 long. 37.05 , on goat dung? in moist chamber, Uppsala, 24 January 1970, Nils Lundqvist 6649-b, F-529978 (holotype UPS!).

Pseudothecia scattered to gregarious, semi-immersed, 550-810 diam $\times 800-1160 \mu \mathrm{m}$ high, subglobose to obpyriform, ostiolate, dark brown to black, opaque, covered with short, white hairs around the base of the neck. Neck short to moderately long, 200-300 diam $\times 200-350 \mu \mathrm{m}$ high, cylindrical. Peridium pseudoparenchymatous. Pseudoparaphyses abundant, filiform, ca. $4 \mu \mathrm{m}$ wide, septate and constricted at the septa, hyaline, mixed with asci. Asci fissitunicate, clavate, eight-spored, 420-475 $\times 58-64 \mu \mathrm{m}$, with a medium long to long stalk. Ascospores eight-celled, cylindrical, (125-) 130-160 × 15-17 $\mu \mathrm{m}$, hyaline to light brown in early stages, becoming reddish-dark brown when mature, break easily into two groups of four cells each, septa transverse, all cells longer than broad, end cells slightly narrower than the other and rounded at apex, germ slits parallel, gelatinous sheath hyaline, narrow.

Etymology:- - the species epithet refers to the eight-celled, cylindrical ascospores.

Habitat and distribution:-Preussia octocylindrospora is to date only known from goat (?) dung in Kenya.

Taxonomic remarks:- This species is distinct by its hairy neck and the long, eight-celled, cylindrical ascospores, which part in the middle and have parallel germ slits. When comparing P. octocylindrospora with other eight-celled Preussia species, the spore size is closest to $S$. insignis, S. octomegaspora and S. splendens, but without matching any of them.

\section{New records}

Sporormiella corynespora (Niessl) S.I. Ahmed \& Cain (1972: 437).

Habitat and distribution:- - The new records were found on rabbit dung in the south of Sweden.

Specimens examined:- SWEDEN. Blekinge: Åryd par., Björkeholmen, on rabbit dung after 1 month in moist chamber, Uppsala, 25 June 1963, Ingvar Nordin 1868u, F-529755 (UPS!); Skåne: Jonstorp par., Svanshall, on rabbit dung in moist chamber, Uppsala, 13 June 1963, Lena Junell 1664n, F-529753 (UPS!).

Taxonomic remarks:-A majority of the previous Swedish records of S. corynespora in Eriksson (2014) are transferred to $P$. octonalis. 

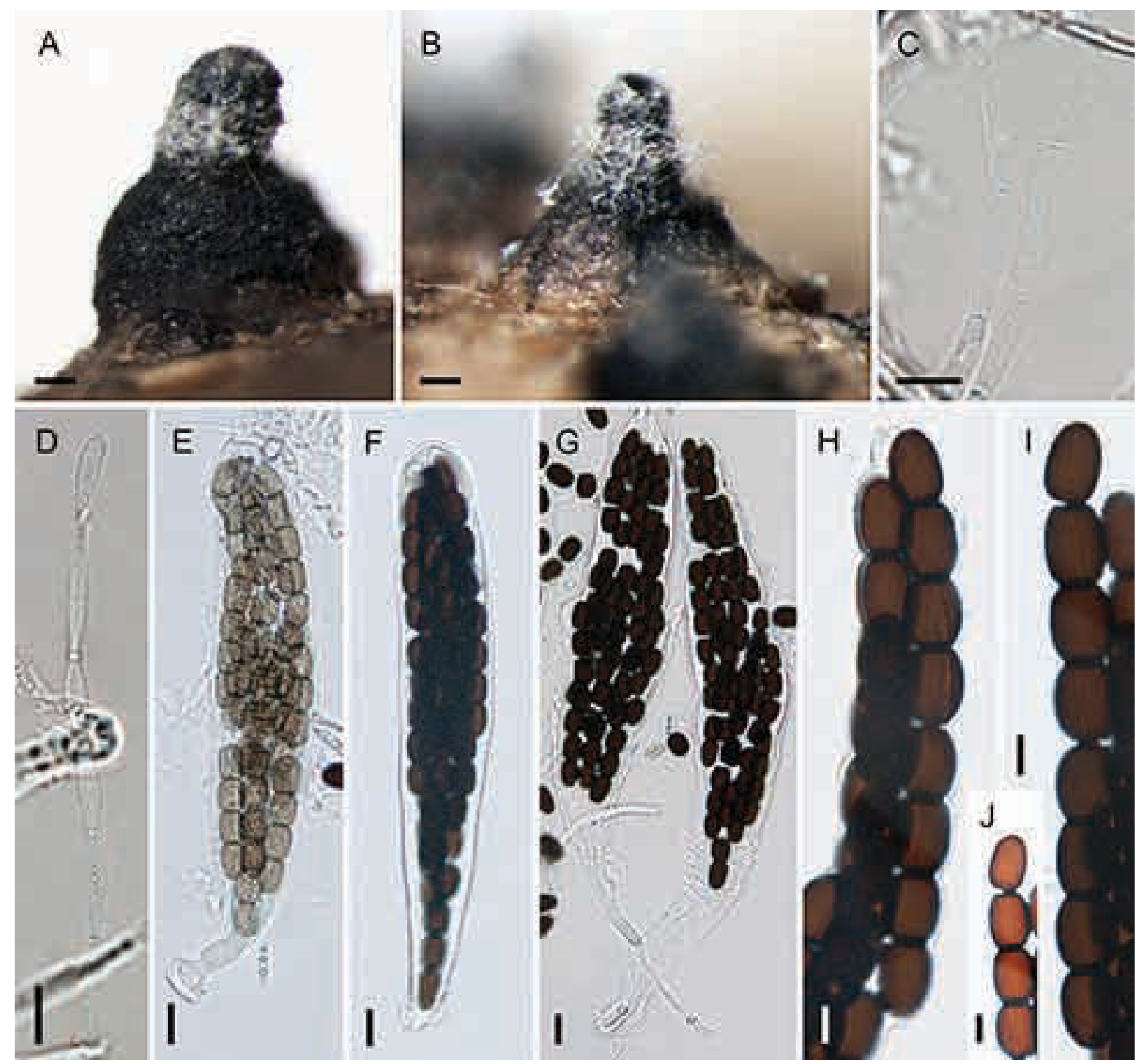

FIGURE 2. Preussia octocylindrospora A-B. ascomata, C-D. pseudoparaphyses E-G. asci, H-I. ascospores. J. part of an ascospore with enhanced germ slits A-J. Coll. F-529978 (UPS). Scale bars: A-B=100 $\mu \mathrm{m}, \mathrm{C}-\mathrm{D}=10 \mu \mathrm{m}, \mathrm{E}-\mathrm{G}=20 \mu \mathrm{m}, \mathrm{H}-\mathrm{J}=10 \mu \mathrm{m}$.

Sporormiella octomegaspora Doveri \& Sarrocco (2013: 130).

Habitat and distribution:- - The species is originally described from red deer dung (Cervus elaphus) in Spain (Doveri \& Sarrocco 2013), and this is the first record from hare dung and Tasmania, Australia.

Specimens examined:-AUSTRALIA. Tasmania: $10 \mathrm{~km}$ ESE of Huonville, Snug Plains, open shrubby area, on hare dung (Lepus europaeus) in moist chamber, Uppsala, 8 March 1981, Tibell 11285-n, F-529944 (UPS!).

Taxonomic remarks:- S. octomegaspora is characterized by large, brown to blackish, rough and densely hairy pseudothecia. Asci are large, eight-spored and have a short stipe, while the ascospores are very long, eight-celled, subfusiform, with sigmoidal germ slits.

Our measurements of the new record F-529944 are for the asci 320-387.5 $\times 52.5-63 \mu \mathrm{m}$, with stipes 12.5-30 $\mu \mathrm{m}$, and for the ascospores 162.5-187.5 $(-192.5) \times 17.5-20 \mu \mathrm{m}$. This record complies with the original description, apart from that these ascospores are a little longer, and their end cells are often slightly longer than the $7^{\text {th }}$ cell, instead of the opposite. Further, according to a sketch by Nils Lundqvist who studied the material when fresh, the germ slit of the end cell is straight and parallel, while the others are sigmoid like the original description. However, considering the small sample size, these discrepancies should not be given too much importance. 
Habitat and distribution:- The new records are from fox and roe deer dung in Sweden.

Specimens examined:-SWEDEN. Uppland: Läby par., Nåsten, in coniferous forest, on roe deer dung, 26 August 1960, Nils Lundqvist 2800-b, F-529757 (UPS!); Södermanland: Åker par., Kvarnberga, on fox dung after 4 weeks in moist chamber, 26 May 1962, Ingvar Nordin 1211d, F-529754 (UPS!).

Preussia octonalis (S.I. Ahmed \& Cain) Soláns, in Valldosera \& Guarro (1990: 88).

Habitat and distribution:- The new records are from Austria, Norway and Sweden. A majority of them are on old cow dung, but there are also single records on horse and sheep dung.

Specimens examined:-AUSTRIA. Tyrol: on cow dung, September 1905. H. Rehm, F256928 (S!). NORWAY. Finnmark: Nord-Varanger par., Varanger peninsula, Vestre Jakobselv, on old sheep dung on the beach, developed in moist chamber, 28 July 1966, Nils Lundqvist 5004-m, F-171385 (UPS!); SWEDEN. Gotland: Östergarn par., Sysne, on the beach, on horse dung in moist chamber, Uppsala, 7 June 1959, Nils Lundqvist 2104-d, F-171379 (UPS!); Halland: Morup par., Morups tånge, on the beach, on cow dung after 25 days in moist chamber, 11 June 1960, Nils Lundqvist 2423c, F-171390 (UPS!); Härjedalen: Vemdalen par., $2 \mathrm{~km} \mathrm{~N}$ of Vemdalen at the bridge over river Veman, in coniferous forest, on old cow dung after 1 month in moist chamber, 15 June 1962, Nils Lundqvist 3397c, F-171380 (UPS!); Jämtland: Mörsil par., 4 km SE of Järpen in coniferous forest, on old cow dung after 4 weeks in moist chamber, 16 June 1962, Nils Lundqvist 3425j, F-171386 (UPS!); Lycksele Lappmark: Stensele par., 4 km SW of Skarvsjö, pasture, on old cow dung, 14 August 1960, Nils Lundqvist 2773b, F-171387 (UPS!); Södermanland: Strängnäs par., Tosterön Island, S of Knäppinge, in a meadow, on cow dung after 23 days in moist chamber, 14 June 1960, Nils Lundqvist 2454a, F-154023 (UPS!); Uppland: Söderby-Karl par., just N of Brölunda on a mountain, on cow dung after 1 month in moist chamber, 4 July 1960, Nils Lundqvist 2513e, F-171389 (UPS!); Ångermanland: Ytterlännäs par., Västertorp, in coniferous forest, on old cow dung after 4 weeks in moist chamber, 20 August 1961, Nils Lundqvist 3165d, F-171383 (UPS!); Åsele lappmark: Vilhelmina par., Meselefors, pasture, on old cow dung, 14 August 1960, Nils Lundqvist 2774a, F-171391 (UPS!); Öland: Bredsätra par., Kapelludden, pasture near the beach, on old cow dung after 21 days in moist chamber, 15 July 1960, Nils Lundqvist 2593k, F-171388 (UPS!); Öland: Ås par., $2 \mathrm{~km} \mathrm{~N}$ of the lighthouse, in a meadow at the beach, on old cow dung after 11 days in moist chamber, 13 July 1960, Nils Lundqvist 2568b, F-171381 (UPS!).

Taxonomic remarks:- - The new records of P. octonalis in Sweden have previously been reported as S. corynespora (Eriksson 2014).

\section{Worldwide key to the coprophilous species of Preussia sensu lato with consistently eight-celled ascospores}

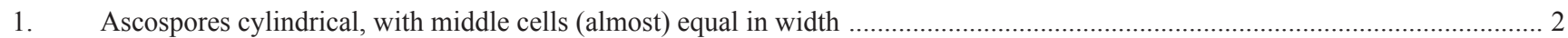

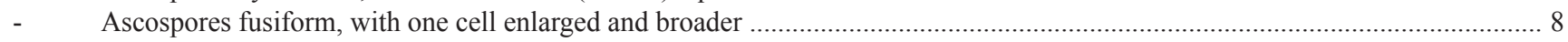

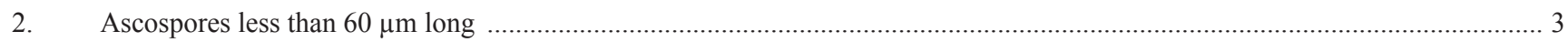

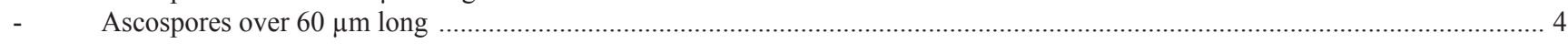

3. Ascospores 48-58 $\times 6-7 \mu \mathrm{m}$, easily part in the middle P. bipartis (Cain) Kruys Ascospores $47-57 \times 12-14 \mu \mathrm{m}$ Sporormia pulchra E. C. Hansen

4. Ascospores with middle cells broader than long 5

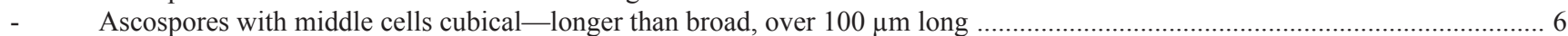

5. Ascospores 79-95 $\times 14-16 \mu \mathrm{m}$, with constrictions at septa deep and broad, end cells ovoid ....... S. platymera S.I. Ahmed \& Cain - $\quad$ Ascospores 72-108 × 14-19 $\mu$ m, with rectangular middle cells and rounded end cells ........... P. tenerifae (Arx \& Guarro) Kruys

6. Ascomata hairy, ascospores $130-160 \times 15-17 \mu \mathrm{m}$, easily part in the middle ................ P. octocylindrospora N. Lundq. \& Kruys

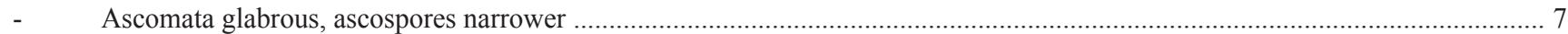




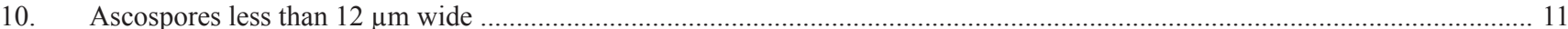

Ascospores more than $12 \mu \mathrm{m}$ wide

11. Asci abruptly ending in a very short stipe, ascospores $52-57 \times 8-9 \mu \mathrm{m}$.............................. S. schadospora S.I. Ahmed \& Cain Asci gently narrowing in a long stipe .......

12. Ascospores 52.5-60 × 9.5-10.5 $\mu \mathrm{m}$ (Doveri 2008), 50-59 × 10-11.5 (Ahmed \& Cain 1972)

S. corynespora (Niessl) S.I. Ahmed \& Cain

Ascospores smaller

13. Ascospores 38-43.5 × 8-9 $\mu \mathrm{m}$ (Doveri 2008), 40-48 × 7-8 (Ahmed \& Cain 1972) P. octomera (Auersw.) Kruys Ascospores $45-52 \times 6-7 \mu \mathrm{m}$ P. alpina N. Lundq. \& Kruys

14. Ascospores with hemispheric end cells, 48.5-63 × 12.5-14.5 $\mu \mathrm{m}$ (Doveri 2008), 48-58 × 12-14 $\mu \mathrm{m}$ (Ahmed \& Cain 1972) ........

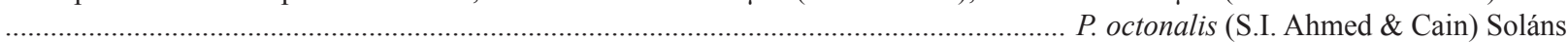
Ascospores with tapered end cells P. affinis (Sacc., E. Bommer \& M. Rousseau) Valldos. \& Guarro

16. Ascospores 34-42 $\times 7 \mu \mathrm{m}$ (Doveri 2008), 32-36 $\times 5.5-6.5 \mu \mathrm{m}$ (Ahmed \& Cain 1972), asci gradually tapering to a short stipe ..... ...................................................................................................... P. minipascua (S.I. Ahmed \& Cain) Kruys Ascospores larger, asci abruptly short-stipitate

17. Ascospores 40-51.5 × 7.5-8.5 $\mu \mathrm{m}$ (Doveri 2008), 40-49 × 8-9 $\mu \mathrm{m}$ (Ahmed \& Cain 1972) Ascospores 49-58 × 9-10 $\mu \mathrm{m}$ (Ahmed \& Cain 1972)

\section{Discussion}

The 8-celled Preussia species have with this study increased in number and diversity. Their morphological variation is great and includes for example a difference in ascospore length of ca $130 \mu \mathrm{m}$ between the smallest and the largest species. This study covers 18 species that occur on dung, but the species number is even higher when including noncoprophilous taxa, those with ascospores of a varying cell number, and some not yet formally described (Doveri \& Sarrocco 2013). The ascospore measurements of some species differ slightly between different authors and I chose to include measurements from both Ahmed \& Cain (1972) and Doveri (2008) in the key. The difference in measurements is probably due to several reasons: there may be geographical varieties of the species, as well as different opinions on species circumscriptions, in combination with the small number of specimens included in many studies.

Coprophilous fungi in general have various preferences of substrates and differ in how general or fastidious they are, as well as how widely distributed they are (Lundqvist 1972, Richardson 2001). Taking account that the number of observations is too low for ecological analyses, the newly described species $P$. alpina seems to have a narrow preference of dung, since it only has been reported on droppings of grouse. It has so far been found in northern Scandinavia, but may have a wider distribution that follows the grouse in alpine and/or arctic regions. The morphologically somewhat similar species P. octomera often occurs on hare or rabbit dung (Furuya \& Udagawa 1972, Doveri 2004, Welt \& Heine 2007, Kruys \& Ericson 2008, Eriksson 2014), but it has also been found on many other different types of dung (Ahmed \& Cain 1972, Kruys \& Ericson 2008, Eriksson 2014), and the new records extend the substrate list to also cover dung of fox and roe deer in Sweden. The new and second record ever of S. octomegaspora greatly extends both the species geographical distribution range (from Spain to Tasmania), as well as its preference of substrate (deer and hare dung). It is possible that the species previously have been found also on Eastern Grey kangaroo dung in Australia, but unfortunately there is no herbarium material available for verification (Bell 2005, Doveri \& Sarrocco 2013). A majority of the new records of $P$. octonalis are on old cow dung, but it was also found on horse and sheep dung. The species has previously been reported from various dung types: e.g. arctic hare, cow, partridge, rabbit and wapiti dung in Canada and USA (Ahmed \& Cain 1972), goat dung in Germany (Welt \& Heine 2007), as well as cattle, pig and roe 
deer dung in Italy (Doveri 2004). The new records of $P$. octonalis shows that the species is fairly common throughout Sweden and not only in the very south as previously believed (Eriksson 2014), which suggests that it likely is to be frequent in neighboring countries as well. The opposite is for S. corynespora, which records decreased significantly with this study. The new records of $S$. corynespora are found on rabbit dung, and leporid dung seems to be a preferred substrate (Ahmed \& Cain 1972, Doveri 2004, Eriksson 2014). It also favors dung of cervids, e.g. deer (Ahmed \& Cain 1972), roe deer (Doveri 2004), and reindeer (Eriksson 2014).

The knowledge of species distribution is constantly improving for the members of Sporormiaceae, as well as for ascomycete fungi in general, due to updated checklists (e.g. Eriksson 1992, 2009, 2014), as well as the digital databases of the natural museum collections. This study, which is based entirely on old herbarium material, also illustrates the great importance of all the natural museum collections. Many interesting specimens and possible new taxa can be found in the herbaria and wait study and description.

\section{Acknowledgements}

Nils Lundqvist is greatly acknowledged for having collected a majority of the material on which this study is based, and for being a great inspiration with all his knowledge. The study is financed by the Swedish Taxonomy Initiative (dha 34/07 1.4), the Helge Ax:son Johnson foundation, and Knigges resestipendium.

\section{References}

Ahmed, S.I. \& Cain, R.F. (1972) Revision of the genera Sporormia and Sporormiella. Canadian Journal of Botany 50: $419-477$. http://dx.doi.org/10.1139/b72-061

Arx von, J.A. \& Müller, E. (1975) A re-evalutation of the bitunicate Ascomycetes with keys to families and genera. Studies in Mycology 9: $1-159$.

Arx von, J.A. \& Storm, P.K. (1967) Über einige aus dem erdboden isolierte, zu Sporormia, Preussia und Westerdykella gehörende ascomyceten. Persoonia 4: 407-415.

Barr, M.E. (2009) A nomenclator of Loculoascomycetous fungi from the Pacific Northwest. North American Fungi 4 (1): 1-94. http://dx.doi.org/10.2509/naf2009.004.001

Bell, A. (2005) An illustrated guide to the coprophilous Ascomycetes of Australia. Centraalbureau voor Schimmelcultures, Utrecht, 172 pp.

Cain, R.F. (1961) Studies of coprophilous ascomycetes. VII. Preussia. Canadian Journal of Botany 39: 1633-1666. http://dx.doi.org/10.1139/b61-144

Danielsen, L., Thürmer, A., Meinicke, P., Buée, M., Morin, E., Martin, F., Pilate, G., Daniel, R., Polle, A. \& Reich, M. (2012) Fungal soil communities in a young transgenic poplar plantation form a rich reservoir for fungal root communities. Ecology and Evolution 2: 1935-1948.

http://dx.doi.org/10.1002/ece3.305

Doveri, F. (2004) Fungi fimicoli Italici. AMB, Fondazione Studi Micologici,Vicenza, 1104 pp.

Doveri, F. (2008) Coprophilous pyrenomycetes s.l. new to Italy after “Fungi Fimicoli Italici”. Bulletin Mycologique et Botanique DauphinéSavoie 48 (191): 71-96.

Doveri, F. \& Sarrocco, S. (2013) Sporormiella octomegaspora, a new hairy species with eight-celled ascospores from Spain. Mycotaxon 123: 129-140. http://dx.doi.org/10.5248/123.129

Dugan, F.M., Roberts, R.G. \& Hanlin, R.T. (1995) New and rare fungi from cherry fruits. Mycologia 87: 713-718. http://dx.doi.org/10.2307/3760817

Eriksson, O.E. (1981) The families of bitunicate ascomycetes. Opera Botanica 60: 1-220. http://dx.doi.org/10.1111/j.1756-1051.1981.tb01167.x

Eriksson, O.E. (1992) The non-lichenized ascomycetes of Sweden. SBT-förlaget, Lund, 208 pp.

Eriksson, O.E. (2009) The non-lichenized ascomycetes of Sweden. Umeå University, Umeå 461 pp.

Eriksson, O.E. (2014) Checklist of the non-lichenized ascomycetes of Sweden. Symbolae Botanicae Upsalienses 36 (2): 1-499.

Furuya, K. \& Udagawa, S-I. (1972) Coprophilous pyrenomycetes from Japan II. The Journal of General and Applied Microbiology 18: 455-467. 
http://dx.doi.org/10.2323/jgam.18.455

Guarro, J., Abdullah, S.K., Gene, J. \& Al-Saadoon, A.H. (1997) A new species of Preussia from submerged plant debris. Mycological Research 101: 305-308.

http://dx.doi.org/10.1017/S0953756296002638

Herrera, J., Khidir, H.H., Eudy, D.M., Porras-Alfaro, A., Natvig, D.O. \& Sinsabaugh, R.L. (2010) Shifting fungal endophyte communities colonize Bouteloua gracilis: effect of host tissue and geographical distribution. Mycologia 102: 1012-1026. http://dx.doi.org/10.3852/09-264

Herrera, J., Poudel, R. \& Khidir, H. (2011) Molecular characterization of coprophilous fungal communities reveals sequences related to root-associated fungal endophytes. Microbial Ecology 61: 239-244 http://dx.doi.org/10.1007/s00248-010-9744-0

Hyde, K.D., Jones, E.B.G., Liu, J.K., Ariyawansa, H., Boehm, E., Boonmee, S., Braun, U., Chomnunti, P., Crous, P.W., Dai, D.Q., Diederich, P., Dissanayake, A., Doilom, M., Doveri, F., Hongsanan, S., Jayawardena, R., Lawrey, J.D., Li, Y.M., Liu, Y.X., Lücking, R., Monkai, J., Muggia, L., Nelsen, M.P., Pang, K.L., Phookamsak, R., Senanayake, I., Shearer, C.A., Suetrong, S., Tanaka, K., Thambugala, K.M., Wijayawardene, N.N., Wikee, S., Wu, H.X., Zhang, Y., Aguirre-Hudson, B., Alias, S.A., Aptroot, A., Bahkali, A.H., Bezerra, J.L., Bhat, D.J., Camporesi, E., Chukeatirote, E., Gueidan, C., Hawksworth, D.L., Hirayama, K., Hoog, S.D., Kang, J.C., Knudsen, K., Li, W.J., Li, X.H., Liu, Z.Y., Mapook, A., McKenzie, E.H.C., Miller, A.N., Mortimer, P.E., Phillips, A.J.L., Raja, H.A., Scheuer, C., Schumm, F., Taylor, J.E., Tian, Q., Tibpromma, S., Wanasinghe, D.N., Wang, Y., Xu, J.C., Yan, J.Y., Yacharoen, S. \& Zhang, M. (2013) Families of Dothideomycetes. Fungal Diversity 63: 1-313.

http://dx.doi.org/10.1007/s13225-013-0263-4

Index Fungorum (2015) Available from: http://www.indexfungorum.org/ (accessed: 11 March 2015)

Khan, R.S. \& Cain, R.F. (1979) The genera Sporormiella and Sporormia in east Africa. Canadian Journal of Botany 57: 1174-1186. http://dx.doi.org/10.1139/b79-141

Kruys, Å. \& Ericson, L. (2008) Species richness of coprophilous ascomycetes in relation to variable food intake by herbivores. Fungal Diversity 30: 73-81.

Kruys, Å. \& Wedin, M. (2009) Phylogenetic relationships and an assessment of traditionally used taxonomic characters in the Sporormiaceae (Pleosporales, Dothideomycetes, Ascomycota), utilising multi-gene phylogenies. Systematics and Biodiversity 7: 465-478. http://dx.doi.org/10.1017/S1477200009990119

Lundqvist, N. (1972) Nordic Sordariaceae s. lat. Symbolae Botanicae Upsalienses 20: 1-374.

Mapperson, R.R., Kotiw, M., Davis, T.A. \& Dearnaley, J.D.W. (2014) The diversity and antimicrobial activity of Preussia sp. endophytes isolated from Australian dry rainforests. Current Microbiology 68: 30-37. http://dx.doi.org/10.1007/s00284-013-0415-5

Mungai, P.G., Njogu, J.G., Chukeatirote, E. \& Hyde, K.D. (2012) Coprophilous ascomycetes in Kenya: Sporormiella from wildlife dung. Mycology 3: 234-251.

Porras-Alfaro, A., Herrera, J., Sinsabaugh, R.L., Odenbach, K.J., Lowrey, T. \& Natvig, D.O. (2008) A novel root fungal consortium associated with a dominant desert grass. Applied and Environmental Microbiology 74: 2805-2813.

http://dx.doi.org/10.1128/AEM.02769-07

Porras-Alfaro, A., Herrera, J., Natvig, D., Lipinski, K. \& Sinsabaugh, R. (2011) Diversity and distribution of soil fungal communities in a semiarid grassland. Mycologia 103: 10-21. http://dx.doi.org/10.3852/09-297

Richardson, M.J. (2001). Diversity and occurrence of coprophilous fungi. Mycological Research 105: 387-402. http://dx.doi.org/10.1017/S0953756201003884

Valldosera, M. \& Guarro, J. (1990) Estudios sobre hongos coprófilos aislados en Espana. XV. El género Preussia (Sporormiella). Boletín de la Sociedad Micológica de Madrid 14: 81-94.

Welt, P. \& Heine, N. (2007) Coprophilous fungi recorded in the reserve area (NSG) "Um den Eibsee" on various substrates and additions to the invertary of fungi found on dung of Angus cows. Zeitschrift für Mykologie 73 (2): 213-244.

Wijayawardene, N.N., Crous, P.W., Kirk, P.M., Hawksworth, D.L., Boonmee, S., Braun, U., Dai, D-Q., D'souza, M.J., Diederich, P., Dissanayake, A., Doilom, M., Hongsanan, S., Jones, G., Groenewald, J., Jayawardena, R., Lawrey, J.D., Liu, J-K., Lücking, R., Madrid, H., Manamgoda, D.S., Muggia, L., Nelsen, M., Phookamsak, R., Suetrong, S., Tanaka, K., Thambugala, K., Wanasinghe, D., Wikee, S., Zhang, Y., Aptroot, A., Ariyawansa, H.A., Bahkali, A., Bhat, J., Gueidan, C., Chomnunti, P., De Hoog, S., Knudsen, K., Li, W-J., McKenzie, E., Miller, A.M., Phillips, A., Piatek, M., Raja, H.A., Shivas, R., Slippers, B., Taylor, J.E., Tian, Q., Wang, Y., Woudenberg, J., Cai, L., Jaklitsch, W. \& Hyde, K.D. (2014) Naming and outline of Dothideomycetes -2014 including proposals for the protection or suppression of generic names. Fungal Diversity 69 (1):1-55.

http://dx.doi.org/10.1007/s13225-014-0309-2 